IJBPAS, May, 2018, 7(5): 923-937

ISSN: 2277-4998

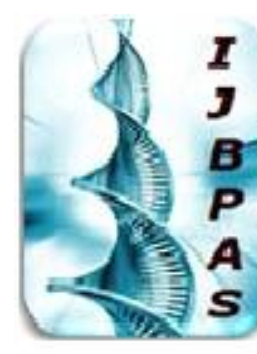

International Journal of Biology, Pharmacy

and Allied Seiences (IJBPAS)

'A B ridge Betuen Caboratory and Qundo'

WwW.ijbpas,com

IN-SILICO STUDIES OF ANDROGRAPHOLIDE, WEDELOLACTONE AND

FENUGREEKINE, AS POTENT ANTI-INFLAMMATORY MEDIATORS

\title{
JAVED IQBAL
}

Faculty of pharmacy, The University of Lahore, Lahore, Pakistan

Corresponding Author: Email: javed.iabal@pharm.uol.edu.pk; Cell: 0321-8448196; Tel: +92 42-

7515460-7, Fax: +92-42-7515519

Received $28^{\text {th }}$ Nov. 2017; Revised $27^{\text {th }}$ Feb. 2018; Accepted $23^{\text {rd }}$ March 2018; Available online $1^{\text {st }}$ May 2018

DOI: https://doi.org/10.31032/IJBPAS/2018/7.5.4450

ABSTRACT

BACKGROUND: Liver is the major internal organ in human body. Plants derived compounds contained efficacy properties against diseases such as cancer, inflammatory diseases, Hepatitis and microbial diseases. Phytochemicals are always potent source of natural oxidants and they serve good therapeutic effects for humankind.

MATERIALS AND METHODS: In present study plants derived compounds are used with known anti-inflammatory action. Four proteins BCL2, COX-1, COX-2 and TNFa involved in inflammatory process were subjected as targeted proteins for protein-ligand docking. These proteins were subjected to molecular docking with selected phytocompounds Andrographolide, Wedelolactone and Fenugreekine. 3D structures were generated by homology modeling approaches utilizing Modeller v9.17. Different evaluation tools including Verify3D, ERRAT and Ramachandran plot assessment were employed to evaluate the predicted structures. Molecular docking studies were performed by AutoDock Vina.

RESULTS: The selected model having satisfactory quality factors results which were BCL2 (81.39\%), COX-1 (86.42\%), COX-2 (93.34) and TNF- $\alpha$ (75.71\%).Post docking analysis revealed that (His-12, Gln-13, Val-14, Glu-15, Arg-30, Ala-31, Asp-34, Phe-35, Arg-38, Lys-57, Gly-58, Trp-75, Gly-76, Val-79, Ile-93, Pro-94, Ser-95, Phe-129, Lys-131, Leu-132, Leu-133, Tyr-133, Phe-135, Asp-316, Gln-319, Lys-327, Lys-501) were observed as important common 
interactive residues and showed that effective binding with target, lower binding affinities and drug properties. The Lipinski rule of 5 (RO5) and ADMET properties illustrated that phytocompoundsare potential inhibitors.

CONCLUSION: Results of present study concluded that phytocompounds (Andrographolide, Fenugreekine and Wedelolactone) expresses significant binding interactions with COX-2 that is an inflammatory protein having major role in liver inflammation. Anti-inflammatory property of aforesaid compounds showed significant anti-inflammatory action and might be used as antiinflammatory drugs therapy in future.

\section{Keyword: Liver damage, COX-2, Andrographolide, Wedelolactone, Fenugreekine INTRODUCTION}

Liver is the largest internal organ of the body playing vital roles by regulating cholesterol via production of urea, bile, hormones and initiate various intermediary metabolisms [1]. Liver also plays an important role in metabolizing fats by production of various substances that convert glucose into glycogen for storage, liver also stores various vitamins and minerals in the biological system that are involved in the production of different amino acids and urea [2]. Moreover it detoxifies harmful toxic materials and initiates first pass metabolism for each foreign particle. Liver damage will results in various diseases such as, cirrhosis, hepatitis and liver cancer etc. Major target of liver damage is alcohol consumption that changes the normal behavior of liver metabolism [3]. As liver acts as detoxifying organ in the biological system but long term consumption of alcohol continuously affects the hepatocyte in induces lethal effects. Besides alcohols long term exposure with Carbon tetrachloride $\left(\mathrm{CCl}_{4}\right)$ also induces liver damage by acting as hepatotoxin. Induction of hepatotoxin leads to damage membrane by producing Reactive Oxygen Species by the process of lipid peroxidation that results in lethal effects biological system and causes cell necrosis. When we talk about its treatment there are various pathways for the treatment of liver damage either through allopathic or through herbal medicine. Investigator's interest has been shifted towards the herbal medicine. Various herbal medicines have been used from many years for the treatment of liver diseases [4]. From $21^{\text {st }}$ century, a significant trend has been shifted to get the knowledge of herbal medicine that has significant antiinflammatory and hepatoprotective role. Plants generate various secondary 
metabolites that plays key role in therapeutic treatment of various liver and other biological diseases [3].

Present research work was designed on the reported properties of phytocompounds; Andrographolide, a pure phytocompound that is extracted from plant Andrographis lineata. It plays significant anti-oxidative, anti-inflammatory and immune modulatory response against chronic hepatitis. Wedelolactone was extracted from Eclipta alba also has been reported having significant anti-inflammatory, membrane stabilizing, anti-fungal and anti-cancer properties. Trigonella foenum- gracium is an ancient plant cultivated since 4000 BC. Mostly present in India, Pakistan, West Asia and Mediterranean.[5] This plant has various metabolites that are responsible for its therapeutic treatment against liver diseases. One of those constituent is Fenugreekine that is used as an anti-diabetic, anti-cancer, antiinflammatory and anti-microbial drug. Present research was designed to evaluate the anti-inflammatory effect of all afore said phyto compounds against different inflammatory proteins including Cyclooxygenase-2 (COX-2), BCL-2, Tumor Necrosis Factor-alpha (TNF- $\alpha$ ) and COX1.Inhibition of COX plays a crucial role as an anti-inflammatory approach.[6] Two inflammatory classes of COX present in the biological system; COX-1 and COX-2 that plays a significant inflammatory response [7]. COX-1 is involved in physiological process and responsible for the development of prostaglandins [8]. Cyclooxygenase-2 (COX-2) prostanoid pathway expresses key roles in induction of various diseases [9]. TNF- $\alpha$ as name shows, is a significant tumor inductive marker levels of TNF- $\alpha$ were increased in inflammatory condition. TNF- $\alpha$ stimulates NF-k $\beta$ that induces liver inflammation through genetic mutation.

\section{MATERIALS AND METHODS STRUCTURE PREDICTION}

3D-structures of the four proteins (Cyclooxygenase-1, Cyclooxygenase-2, $\mathrm{TNF} \alpha$ and $\mathrm{Bcl} 2$ ) were taken as target from Rattus norvegicus organism. The amino acid sequence of four proteins COX-1 (602a.a), COX-2 (604 a.a), TNFa (235 a.a) and Bcl2 (236 a.a) were used for homology modeling. The sequences of four proteins were retrieved from Uniprot Knowledge base (http://www.uniprot.org/) in FASTA format. Table 1 demonstrates the templates of all four proteins selected on query coverage, identity, total score and e-value. The best suitable templates were used for 3D-structure prediction. The retrieved amino acid sequences of four proteins were subjected to 
BLASTp [10] for the identification of suitable template search against the Protein Data Bank (PDB) [11]. Templates were retrieved on the base of identity and query coverage. The 3D-structures were predicted by MODELLER as the requirement of $3 \mathrm{D}$ structure building of targeted protein. Various online evaluation tools were used; Rampage [12] ERRAT [13] and verify-3D [14]. The structure refinement of selected proteins was performed by UCSF Chimera. The energy minimization of targeted proteins was performed by UCSC Chimera 1.11 [15] and utlized steepest decent and conjugates gradient 1000 runs with Amber force field parameters.

\section{LIGANDS PREPARATIONS}

Andrographolide, Fenugreekine and Wedelolactone were searched from Chem Idplus[16]and Pubchem[17]. The phytocompounds were drawn by ChemDraw Ultra[18], energyminimized by Chem3D Pro[19]. Further geomatery optimization and energyminimation of selected small molecules were performed by Avogadros tool and UCSF Chimera v1.11 at 1500 steepest and 1500 conjugate gradiant runs.PDBQTof minimized ligands prepared by AutoDock MGTOOLS for protein-ligand docking and PDBQT was used for molecular docking.

\section{MOLECULAR DOCKING STUDIES}

Andrographolide, Wedelolactone and Fenugreekine were used for protein-ligand docking against targeted proteins BCL2, COX-1, COX-2, and TNFa. PDBQT of minimized ligands were used for docking. The binding sites were predicted from different online tools including $\mathrm{COACH}$ [20], RaptorX binding [21] and from literature. The minimized proteins were used for docking and docking grid set around the selected binding sites of proteins. The molecular docking analyses were performed by AutoDock Vina.[22]The docking results were analysed and visualized by Chimera v1.11. The Rule of five was calculated by using mCule server [23]. ADMET (absorption, distribution, metabolism, excretion and toxicity) properties of three selected phytocompounds were calculated from admet SAR online server [24].

\section{RESULTS}

\section{STRUCTURE PREDICTION}

The sequences of the selected four proteins (BCL2, COX-1, COX-2 and TNF $\alpha$ ) were subjected to BlastP against PDB to search suitable templates for each selected protein with maximum identity, query coverage and E-value subjected to homology modeling. The selected templates were utilized to generate 3D structures of targeted 
proteins by homology modeling approach. Approximately $>85 \%$ overall query coverage and identity were shown in targeted templates from end to end that was considered satisfactory reliable structures by homology modeling approach for all selected proteins.All the 3D generated models of the selected proteins were evaluated and selected the most reliable model on the basis of their quality score, favored region, allowed region and outliers (Figure 1).

\section{MOLECULAR DOCKING ANALYSIS}

From comprehensive literature survey, $\quad 3$ phytocompounds (Andrographolide, Fenugreekine and Wedelolactone) were selected to identify the binding sites of four selected proteins by using molecular docking approaches. The binding sites of selected proteins were also predicted from different online tools including $\mathrm{COACH}$ and RaptorX binding. Additionally, the confirmation of the binding sites for selected proteins was studies from related literature. The docking analyses were performed against the 3 selected phytocompounds by utilizing AutoDock
Vina. The docking studies were executed with 100 runs and all the generated docked complexes were studied. The top-ranked docked complex having highest binding affinity and lowest binding energy were selected for each protein. The utilizing docking tools showed the similar interactive residues and also showed the effective binding affinities. The binding affinities of the selected phytocompounds were observed in between -6.4 to $-9.7 \mathrm{kcal} / \mathrm{mol}$ and enlisted in Table 2. The lowest binding energy was observed $-9.7 \mathrm{kcal} / \mathrm{mol}$ of Fenugreekine against $\mathrm{COX}-2, \quad-8.8 \quad \mathrm{kcal} / \mathrm{mol}$ of Wedelolactone against TNF- $\alpha$ and -8.0 $\mathrm{kcal} / \mathrm{mol}$ of Andrographolide against COX-2. The molecular analyses also observed shared the common binding regionsand common interactive residues that are displayin Figure 4, 5, 6, 7 and Table 3 respectively. The Rule of-5 properties of selected ligands were calculated by mCule server (Table 4 ). The ADMET profile was analysed by admetSAR server and showed that the selected phytocompounds have non-carcinogenic (Table 5).

\begin{tabular}{|c|c|c|c|c|c|}
\hline Name of Protein & Accession Number & Max Score & $\begin{array}{c}\text { Query } \\
\text { Coverage }\end{array}$ & Identity & E-Value \\
\hline BCL2 & 2XA0 & 336 & $86 \%$ & $86 \%$ & $3 e-118$ \\
\hline Cyclooxygenase-2 & 1PXX & 1227 & $100 \%$ & $96 \%$ & 0.0 \\
\hline TNF- $\alpha$ & 2TNF & 309 & $89 \%$ & $95 \%$ & $2 e-109$ \\
\hline
\end{tabular}


Table 2: Binding affinities of phytocompounds against targeted proteins

\begin{tabular}{cccc}
\hline Target Proteins & $\begin{array}{c}\text { Binding affinities (Kcal/mol) of } \\
\text { phytocompounds } \\
\text { (Andrographolide) }\end{array}$ & $\begin{array}{c}\text { Binding affinities (Kcal/mol) of } \\
\text { phytocompounds } \\
\text { (Fenugreekine) }\end{array}$ & $\begin{array}{c}\text { Binding affinities (Kcal/mol) of } \\
\text { phytocompounds (Wedelolactone) }\end{array}$ \\
BCL2 & -7.0 & -6.4 & -7.1 \\
COX-1 & -7.5 & -9.0 & -8.4 \\
COX-2 & $-\mathbf{8 . 0}$ & -9.7 & -8.4 \\
TNF- $\alpha$ & -7.8 & -7.4 & -8.8 \\
\hline
\end{tabular}

Table 3: Interactive residues involved in binding pockets

\begin{tabular}{|c|c|c|c|}
\hline Target proteins & $\begin{array}{l}\text { Interactive residues of ligand- } \\
\text { protein docked complex } \\
\text { (Andrographolide) }\end{array}$ & $\begin{array}{l}\text { Interactive residues of ligand- } \\
\text { protein docked complex } \\
\text { (Wedelolactone) }\end{array}$ & $\begin{array}{l}\text { Interactive residues of ligand-protein } \\
\text { docked complex (Fenugreekine) }\end{array}$ \\
\hline BCL2 & $\begin{array}{c}\text { Ala-31, Asp-34, Phe-35,Trp-75, } \\
\text { Gly-76, Val-79, Phe-129, Leu- } \\
\text { 132, Tyr-133 }\end{array}$ & $\begin{array}{c}\text { Ala-31, Phe-35, Arg-38, Trp- } \\
\text { 75, Gly-76, Val-79, Phe-129, } \\
\text { Leu-132, Tyr-133 }\end{array}$ & $\begin{array}{l}\text { Ala-31,Asp-34, Phe-35, Arg-38, Trp- } \\
\text { 75, Gly-76, Val-79, Phe-129, Tyr-133, } \\
\text { Ser-136 }\end{array}$ \\
\hline Cyclooxygenase-1 & $\begin{array}{l}\text { Gln-13, Ile-15, Arg-30, Ile-93, } \\
\text { Pro-94, Ser-95, Thr-98, Arg- } \\
\text { 438, Lys-501 }\end{array}$ & $\begin{array}{l}\text { Gln-13, Asn-91, Leu-92, Pro- } \\
\text { 94, Ser-95, Pro-96, Thr-98, } \\
\text { Ile-106, Arg-438 }\end{array}$ & $\begin{array}{l}\text { GIn-13, Arg-30, Thr-31, Tyr-33, Thr- } \\
\text { 45, Arg-48, Thr-49, Arg-52, Ser-90, } \\
\text { Asn-91, Ile-93, Pro-94, Ser-95, Pro- } \\
\text { 96, Phe-340, Lys-501 }\end{array}$ \\
\hline Cyclooxygenase-2 & $\begin{array}{c}\text { Asn-72, Asp-316, GIn-319, His- } \\
\text { 320, His-325, Lys-327, Ser-548, } \\
\text { Asn-550, Gln-552 }\end{array}$ & $\begin{array}{l}\text { Asp-316, Gln-319, His-325, } \\
\text { Lys-327, Ser-548, Phe-549, } \\
\text { Asn-550 }\end{array}$ & $\begin{array}{l}\text { Glu-315, Asp-316, Gln-319, Gly-323, } \\
\text { Tyr-324, Lys-327, Ser-532, Gln-534 }\end{array}$ \\
\hline TNF- $\alpha$ & $\begin{array}{l}\text { Glu-15, Glu-16, Lys-57,Lys- } \\
\text { 131, Leu-133, Phe-135, Ala-136 }\end{array}$ & $\begin{array}{l}\text { His-12, Gln-13, Val-14, Glu- } \\
\text { 15,Lys-57, Gly-58, Lys-131, } \\
\text { Phe-135 }\end{array}$ & $\begin{array}{l}\text { His-12, Gln-13, Val-14, Glu-15,Lys- } \\
\text { 57, Gly-58, Gln-59, Leu-102, Lys-131, } \\
\text { Tyr-132, Leu-133 }\end{array}$ \\
\hline
\end{tabular}

Table 4: Drug properties of selected phytocompounds

\begin{tabular}{|c|c|c|c|}
\hline Properties & Andrographolide & Wedelolactone & Fenugreekine \\
\hline $\operatorname{Mass}(\mathrm{g} / \mathrm{mol})$ & 350.4483 & 314.2452 & 663.4250 \\
\hline $\log P$ & 1.9626 & 2.8178 & -1.0844 \\
\hline H-bond acceptors & 5 & 7 & 21 \\
\hline H-bonds donors & 3 & 3 & 8 \\
\hline Rotatable bonds & 3 & 1 & 11 \\
\hline PSA & 86.9900 & 113.2700 & 346.8900 \\
\hline RO5 violations & 0 & $\mathbf{0}$ & 3 \\
\hline Atoms & 55 & 33 & 71 \\
\hline Rings & 3 & 4 & 5 \\
\hline Pronerties & Androgranbolide & Wolotomp & Fenugreokine \\
\hline $\begin{array}{c}\text { Properties } \\
\text { Blood-Brain Barrier } \\
\text { (Probability) }\end{array}$ & $\begin{array}{c}\text { Andrographolide } \\
\text { BBB+ } \\
(\mathbf{0 . 8 1 3 5})\end{array}$ & $\begin{array}{c}\text { Wedelolactone } \\
\text { BBB+ } \\
(\mathbf{0 . 6 2 2 4})\end{array}$ & $\begin{array}{c}\text { Fenugreekine } \\
\text { BBB+ } \\
(0.7742)\end{array}$ \\
\hline $\begin{array}{c}\text { Human Intestinal absorption } \\
\text { (Probability) }\end{array}$ & $\begin{array}{c}\text { HIA+ } \\
(0.9155)\end{array}$ & $\underset{(0.8815)}{\text { HIA+ }}$ & $\begin{array}{c}\text { HIA+ } \\
(0.7270)\end{array}$ \\
\hline $\begin{array}{l}\text { AMES Toxicity } \\
\text { (Probability) }\end{array}$ & $\begin{array}{c}\text { Non AMES Toxic } \\
(\mathbf{0 . 8 7 1 4})\end{array}$ & $\begin{array}{c}\text { Non AMES Toxic } \\
(\mathbf{0 . 7 7 6 0 )}\end{array}$ & $\begin{array}{c}\text { Non AMES Toxic } \\
(0.8930)\end{array}$ \\
\hline $\begin{array}{l}\text { Carcinogens } \\
\text { (Probability) }\end{array}$ & $\begin{array}{c}\text { Non-carcinogens } \\
(0.9618)\end{array}$ & $\begin{array}{c}\text { Non-carcinogens } \\
(\mathbf{0 . 9 6 5 8})\end{array}$ & $\begin{array}{c}\text { Non-carcinogens } \\
(\mathbf{0 . 9 1 1 2 )}\end{array}$ \\
\hline Aqueous solubility (Logs) & -2.8534 & -3.2335 & -3.0145 \\
\hline Biodegradation & $\begin{array}{c}\text { Not ready biodegradable } \\
(\mathbf{0 . 9 5 3 5 )}\end{array}$ & $\begin{array}{c}\text { Not ready biodegradable } \\
(\mathbf{0 . 8 4 7 5 )}\end{array}$ & $\begin{array}{c}\text { Not ready biodegradable } \\
(0.9911)\end{array}$ \\
\hline Acute Oral Toxicity & $\begin{array}{c}\text { III } \\
(\mathbf{0 . 5 3 2 8})\end{array}$ & $\underset{(0.5546)}{\text { III }}$ & $\begin{array}{c}\text { II } \\
(\mathbf{0 . 4 5 5 8 )}\end{array}$ \\
\hline
\end{tabular}



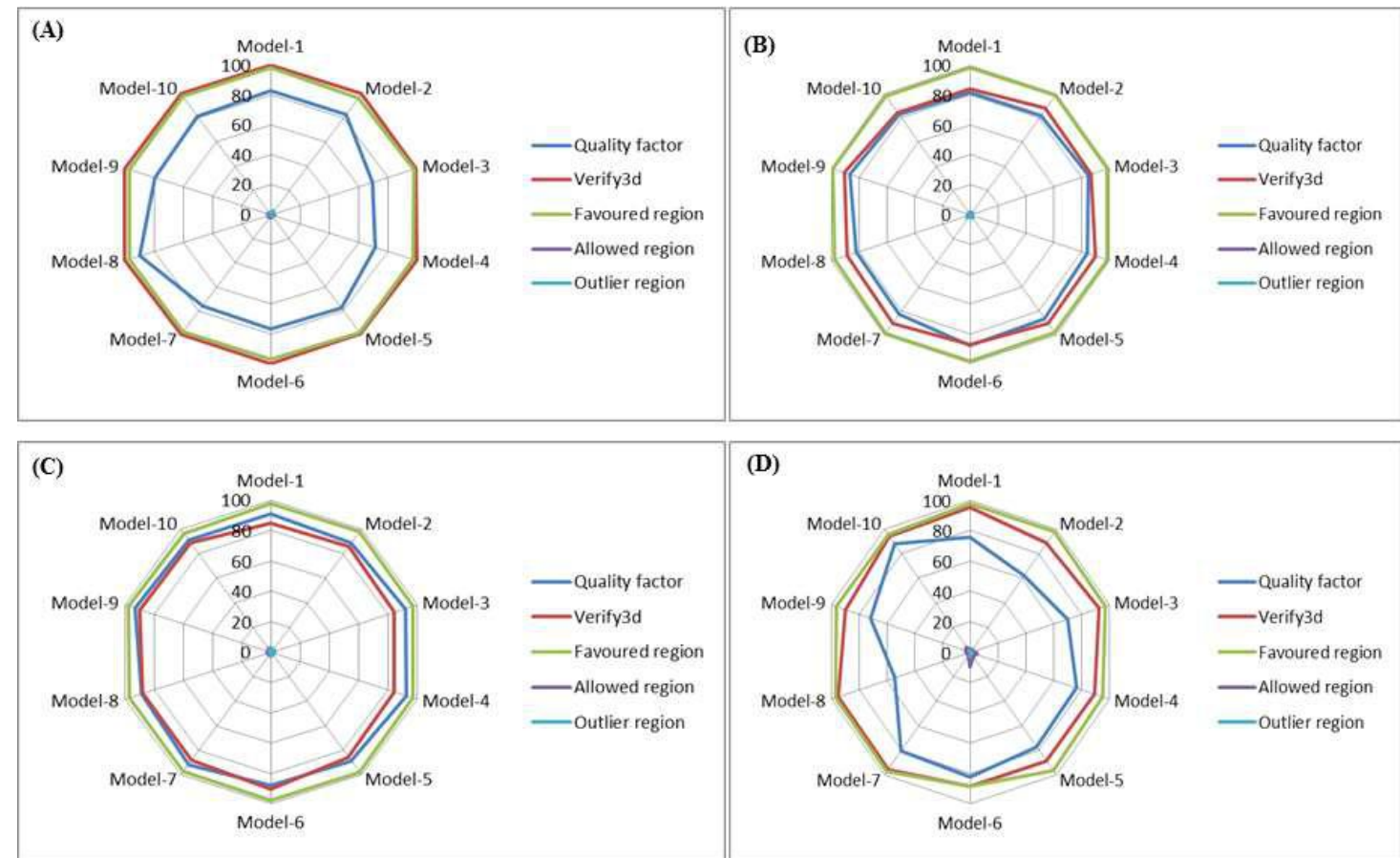

Figure 1: The Comparative model assessment plot showed Ramachandran plot assessment favored, allowed and outlier regions, overall quality factor and Verify3 assessment score. (A) Graphical depiction of BCL2, (B) Graphical depiction of COX-1, (C) Graphical depiction of COX-2 and (D) Graphical depiction of TNF-alpha

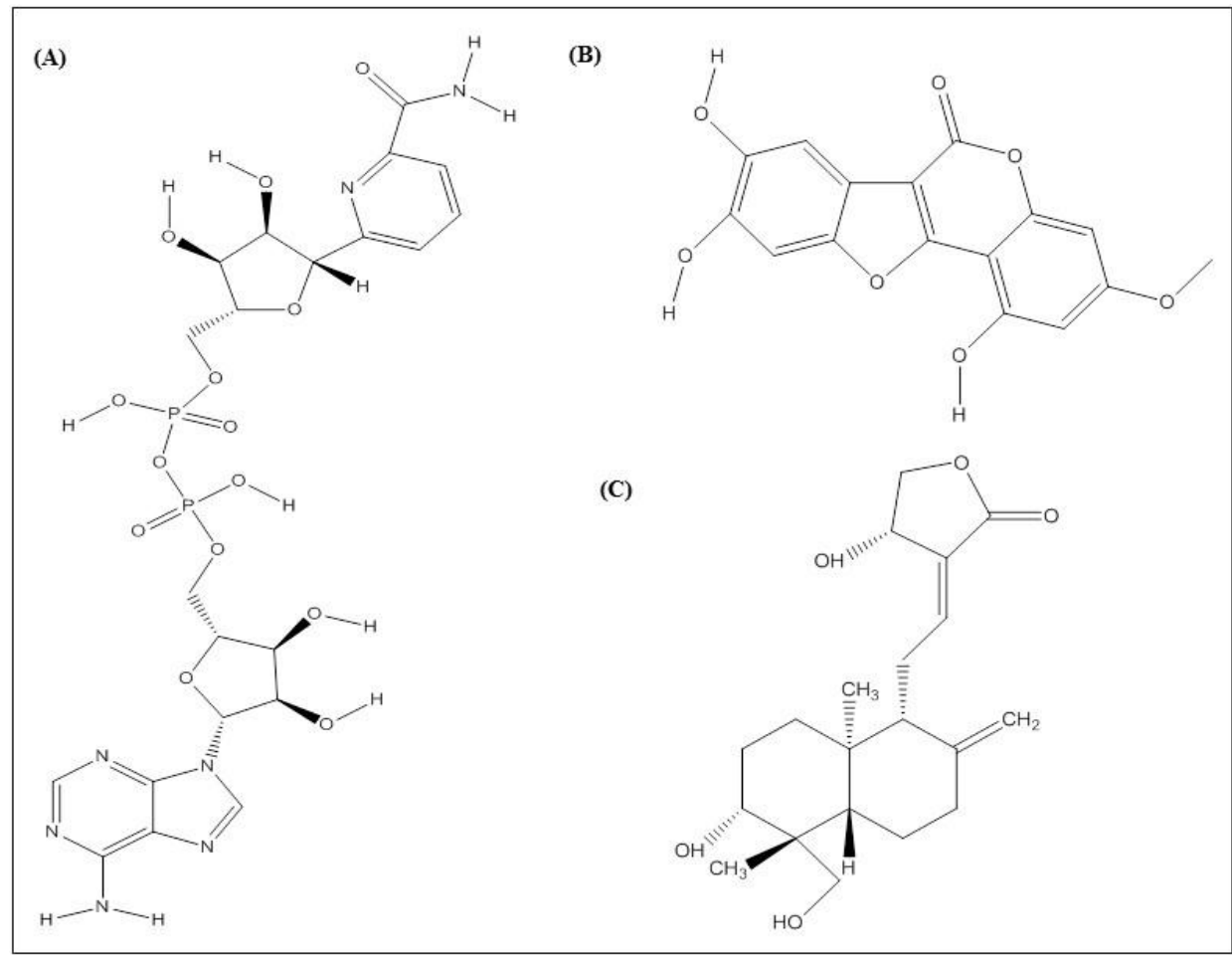

Figure 2: The 2D-chemical structures representation of Phytocompounds (A). Fenugreekine, (B). Andrographolide (C). Wedelolactone

The chemicals were manually drawn by ChemDraw and then convert into the .pdb file for refinement of selected phytochemicals. After refinement of selected phytocompounds, then convert into the PDBQT which was used for docking studies 

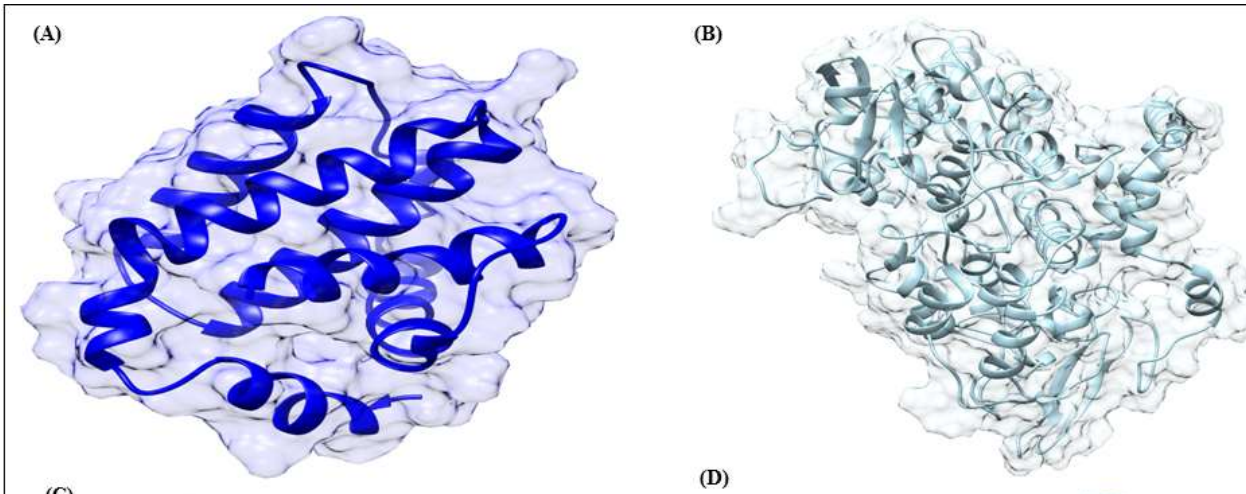

(C)

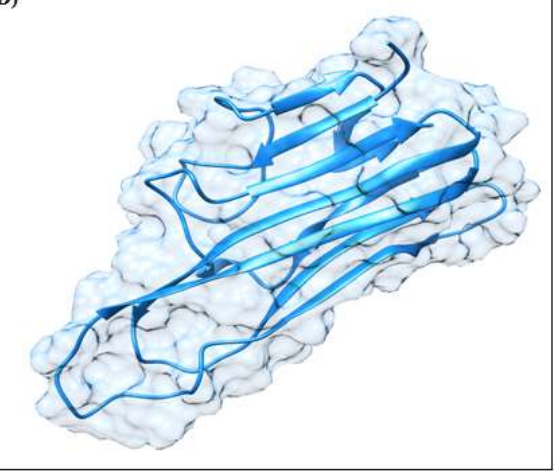

Figure 3: 3D minimized selected structures of four proteins. The minimized proteins are display in different colors (round ribbon style, $90 \%$ transparency(A).BCL2 in blue, (B). COX-1 in light blue, (C). COX-2 in white and (D). TNF-alpha in dodger blue

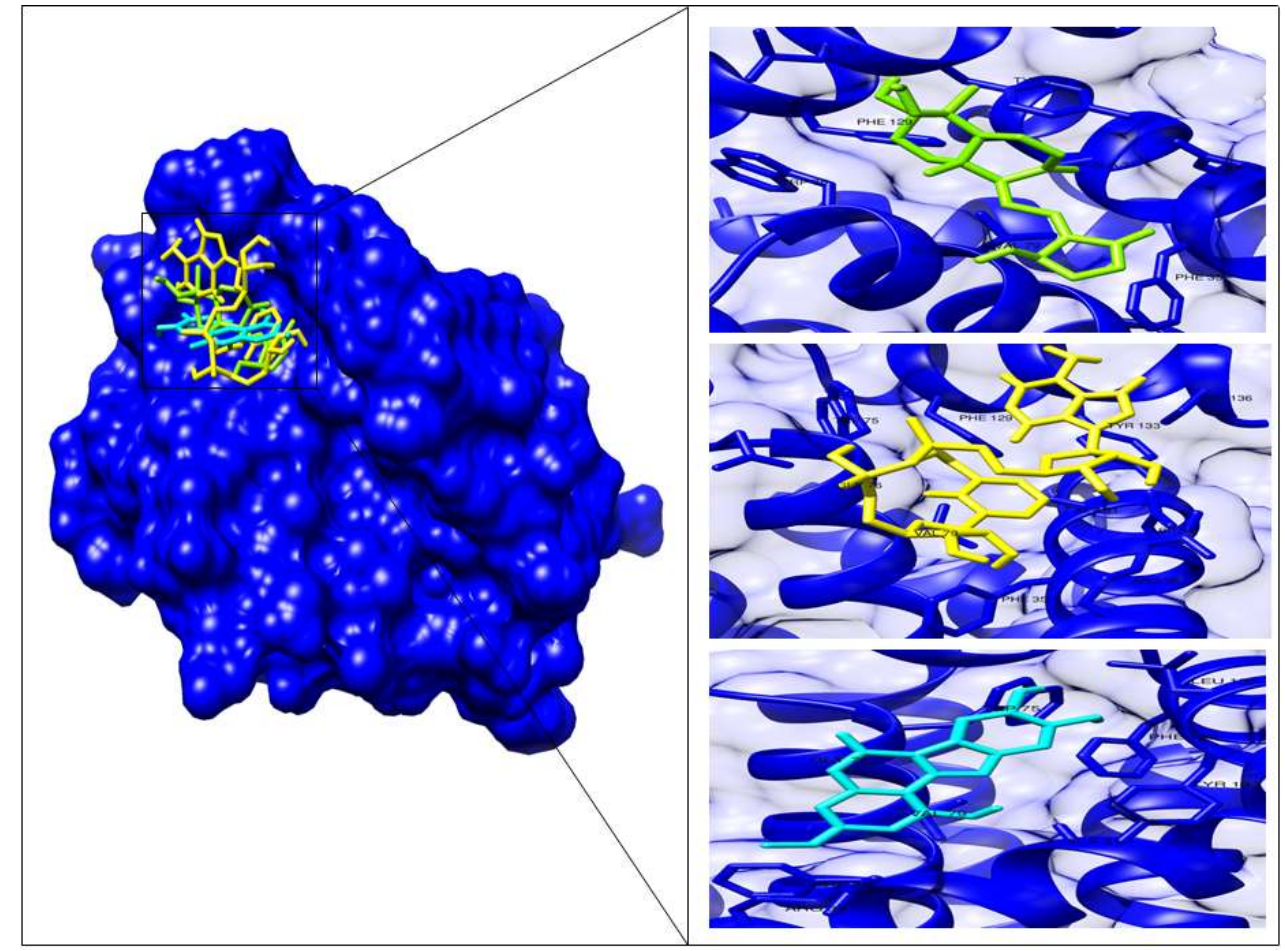

Figure 4: Binding interactions of docked poses. The targeted protein (BCL2) is display in round ribbon stylein Blue color. Andrographolide (in chartreuse color), fenugreekine (in yellow color) wedelolactone (in cyan color) and also display the binding residues 


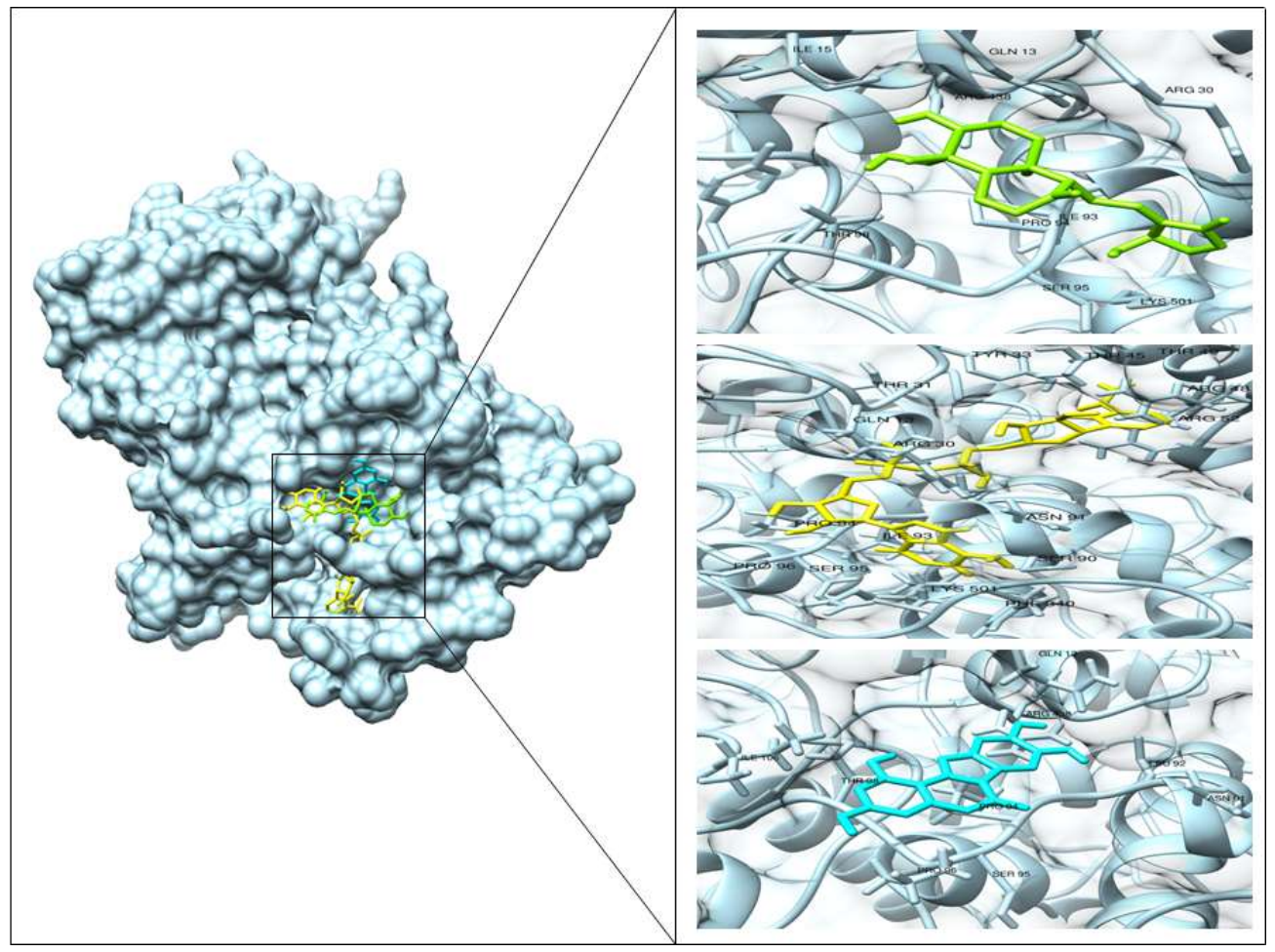

Figure 5: Binding interactions of docked poses. The targeted protein (COX1) is display in round ribbon style in light blue color. Andrographolide (in chartreuse color), fenugreekine (in yellow color) wedelolactone (in cyan color) and also display the binding residues.

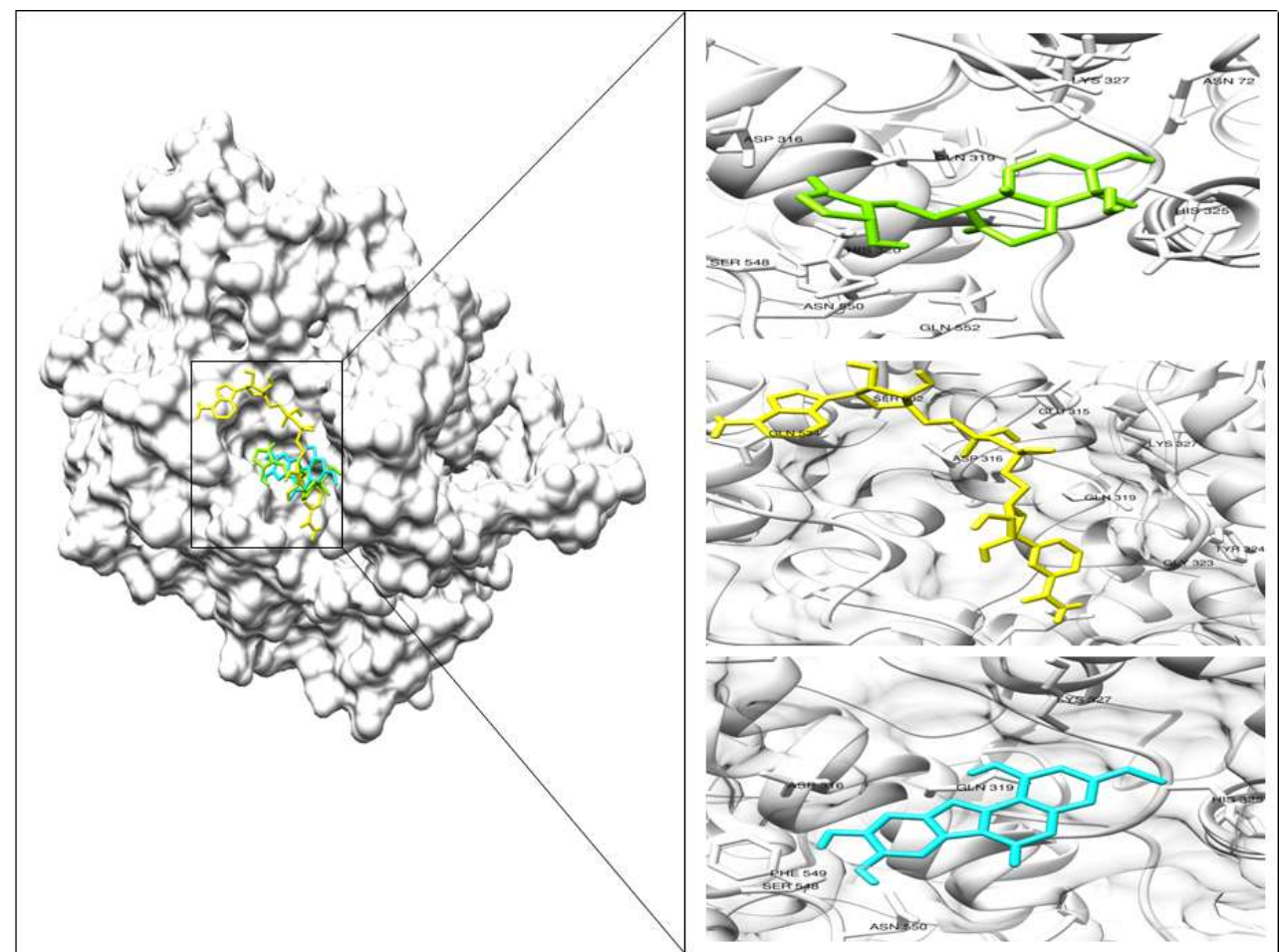

Figure 6: Binding interactions of docked poses. The targeted protein (COX2) is display in round ribbon style in white color. Andrographolide (in chartreuse color), fenugreekine (in yellow color) wedelolactone (in cyan color) and also display the binding residues 


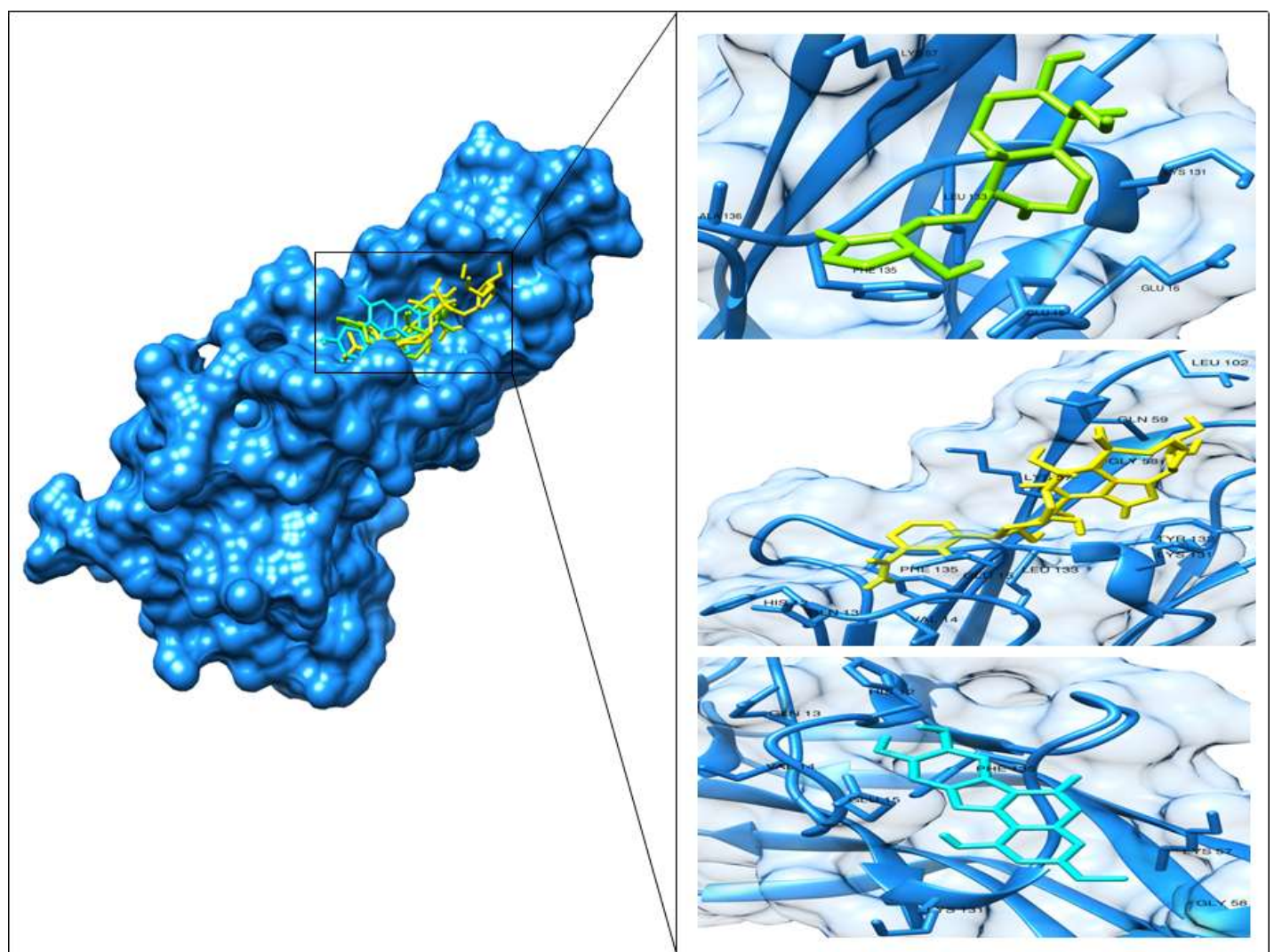

Figure 7: Binding interactions of docked poses. The targeted protein (TNF- $\alpha$ ) is display in round ribbon style in dodger blue color. Andrographolide (in chartreuse color), fenugreekine (in yellow color) wedelolactone (in cyan color) and also display the binding residues.

\section{DISCUSSION}

The secondary metabolism of plants has potent phytochemicals which areused as therapeutic agents against anti-viral, antiinflammatory and immune disorders.[25] Phytocompounds of plants have good effects in health.[26] Plnats carries best source regarding to novel drug compounds.[27]Structural bioinformatics are help to cure inflammatory disorders and cancer through novel computer drug designing.[28]In previous literature, For Bcl2 some key residues were identified (Ala-97,
Asp-100, Phe-101, Arg-104, Tyr-105, Asp108, Phe109, Met-112, Val-130, Val-133, Leu-134, Asn-140, Trp-141, Gly-142, Arg143, Val-145, Ala-146, Glu-149, Phe-150, Val-153, Phe-195, Leu-198, Tyr-199, Gly200) from literature.[29] The previous study indicate 1XJ ligand bind with Bcl-2 that interact with these residues. In current study, all ligands are bind at same position (Figure 4). Current docking analysis revealed that some particular residues are involved in mutant structure such as Tyr133Glu. Similarly, for COX-1 key interactive residues 
were observed (Val-116, Arg-120, Tyr-348, Val-349, Leu-352, Ser-353, Tyr-355, Leu359, Phe-381, Leu-384, Tyr-358, Trp-387, Phe-518 Met-522, Ile-523, Gly-526, Ala527, Ser-530 and Leu531) in FLP ligand with COX-1 complex.[30] In current study, all selected ligands were bind at same binding pocketes (Figure 5). In previous In Vitro studies also proved that inhibitry actions of ibuprofen confirmed from X-ray crystallography analyses that showed some interactions with (Arg-120, Phe382, Tyr-385, Trp-387, Ser-530, Ser-531, Leu-532) these key residues.[31] Current docking analyses indicated some mutant residues as like Ser532Leu. All ligands were bind at same position (Figure 6). In case of TNF- $\alpha$, previously reportedx-ray crystallography studies proved that small molecules showed effective activity in cell based assays and biochemical studies. Some key interactions were (Leu-55, Leu-57, Ile-58, Tyr-59, Ser60, Gln-61, Tyr-119, Leu-120, Gln-121, Gln122, Tyr-151, Ile-155 and Ile-157) are playing key role in the inhibition of TNF$\alpha .[32]$ All ligands were bind at same position (Figure 7). Current docking study revealed that some mutant residues such as Lys57Leu, Leu58Ile, and Gln59Tyr. However, current in silico and in vivo studies revealed that all three selected phytocompounds

(Andrographolide, Fenugreekine and Wedelolactone) have potent inhibition, strong binding interactions, and interactive residues followed by molecular docking. So, these three selected phytocompounds are promising therapeutic agents against $\mathrm{Bcl}-2, \mathrm{COX}-1, \mathrm{COX}-2$ and TNF- $\alpha$.

\section{CONCLUSION}

In conclusion, the selected phytocompounds is highly efficacious in the remedies of inflammatory disorders for targeting COX-1, COX-2, TNF $\alpha$ and $\mathrm{Bcl} 2$. Analysis of In-Silico studies of targeting proteins with subjected ligands has lowest binding affinity, highest gold fitness score and interactive residues. Following studies proved that these phytocompounds (Andrographolide, Wedelolactone and Fenugreekine) have prime importance as anti-inflammatory and anti-cancer therapeutic drugs. Computational aided drug designing studies provides strong pillar of clue for drug discovery.

\section{ACKNOWLEDGEMENTS}

The authors are highly thankful for the valuable contribution of student of LAB313 (Biology of stress tolerance), Institute of Molecular Biology and Biotechnology, The University of Lahore-Pakistan. 


\section{CONFLICT OF INTEREST}

Authors declare no conflict of interest.

\section{REFERENCES}

[1] Gao B, Jeong WI, Tian Z. Liver: an organ with predominant innate immunity. Hepatology. 2008 Feb 1; 47(2):729-36.

[2] Shu M, Huang DD, Hung ZA, Hu XR, Zhang S. Inhibition of MAPK and NF- $\kappa$ B signaling pathways alleviate carbon tetrachloride $(\mathrm{CCl} 4)$ induced liver fibrosis in Toll-like receptor 5 (TLR5) deficiency mice. Biochemical and biophysical research communications. $2016 \quad$ Feb 26;471(1):233-9.m

[3] Morita I. Distinct functions of COX-1 and COX-2. Prostaglandins \& other lipid mediators. 2002 Aug 1; 68: 16575.

[4] Sethi G, Sung B, Aggarwal BB. TNF: a master switch for inflammation to cancer. Front Biosci. 2008 May 1; 13(2): 5094-107.

[5] Bahmani M, Shirzad H, Mirhosseini M, Mesripour A, Rafieian-Kopaei M. A review on ethnobotanical and therapeutic uses of fenugreek (Trigonella foenum-graceum L). Journal of evidence-based complementary \& alternative medicine. 2016 Jan; 21(1):53-62.

[6] Reilly TP, Brady JN, Marchick MR, Bourdi M, George JW, Radonovich MF, Pise-Masison CA, Pohl LR. A protective role for cyclooxygenase-2 in drug-induced liver injury in mice. Chemical research in toxicology. 2001 Dec 17; 14(12):1620-8.

[7] Dubois RN, Abramson SB, Crofford L, Gupta RA, Simon LS, Van De Putte LB, Lipsky PE. Cyclooxygenase in biology and disease. The FASEB journal. 1998 Sep 1;12(12):1063-73.

[8] Crofford LJ. COX-1 and COX-2 tissue expression: implications and predictions. The Journal of Rheumatology. Supplement. 1997 Jul; 49: 15-9.

[9] Hu KQ. Cyclooxygenase 2 (COX2)prostanoid pathway and liver diseases. Prostaglandins, leukotrienes and essential fatty acids. 2003 Nov 1; 69(5): 329-37.

[10] Altschul SF, Gish W, Miller W, Myers EW, Lipman DJ. Basic local alignment search tool. Journal of molecular biology. 1990 Oct 5; 215(3): 403-10. 
[11] Berman HM, Westbrook J, Feng Z, Gilliland G, Bhat TN, Weissig H, Shindyalov IN, Bourne PE. The protein data bank, 1999-. InInternational Tables for Crystallography Volume F: Crystallography of biological macromolecules 2006 (pp. 675684). Springer Netherlands.

[12] Lovell SC, Davis IW, Arendall WB, De Bakker PI, Word JM, Prisant MG, Richardson JS, Richardson DC. Structure validation by $\mathrm{C} \alpha$ geometry: $\phi, \psi$ and $\mathrm{C} \beta$ deviation. Proteins: Structure, Function, and Bioinformatics. $2003 \quad$ Feb 15;50(3):437-50.

[13] Colovos C, Yeates TO. Verification of protein structures: patterns of nonbonded atomic interactions. Protein science. 1993 Sep 1; 2(9): $1511-9$

[14] Eisenberg D, Lüthy R, Bowie JU. [20] VERIFY3D: Assessment of protein models with threedimensional profiles. InMethods in enzymology 1997 Jan 1 (Vol. 277, pp. 396-404). Academic Press.

[15] Pettersen EF, Goddard TD, Huang CC, Couch GS, Greenblatt DM, Meng EC, Ferrin TE. UCSF
Chimera - a visualization system for exploratory research and analysis. Journal of computational chemistry. 2004 Oct 1; 25(13):1605-12.

[16] https://chem.nlm.nih.gov/chemidplu s/

[17] Bolton EE, Wang Y, Thiessen PA, Bryant SH. PubChem: integrated platform of small molecules and biological activities. InAnnual reports in computational chemistry 2008 Jan 1 (Vol. 4, pp. 217-241). Elsevier.

[18] Mendelsohn LD. ChemDraw 8 ultra, windows and macintosh versions. Journal of Chemical Information and Computer Sciences. 2004 Nov 22; 44(6): 2225-6.

[19] Hinchliffe A. CS Chem3D Pro 3.5 and CS MOPAC Pro (Mac and Windows) UK. Electronic Journal of Theoretical Chemistry. 1997 Jan 1; 2(1): 215-7.m

[20] Yang J, Roy A, Zhang Y. Proteinligand binding site recognition using complementary binding-specific substructure comparison and sequence profile alignment. Bioinformatics. 2013 Aug 23; 29(20): 2588-95. 
[21] Källberg M, Wang H, Wang S, Peng J, Wang Z, Lu H, Xu J. Templatebased protein structure modeling using the RaptorX web server. Nature protocols. 2012 Aug; 7(8):1511.

[22] Trott O, Olson AJ. AutoDock Vina: improving the speed and accuracy of docking with a new scoring function, efficient optimization, and multithreading. Journal of computational chemistry. 2010 Jan 30; 31(2): 455-61.

[23] Kiss R, Sandor M, Szalai FA. http://Mcule. com: a public web service for drug discovery. Journal of cheminformatics. 2012 Dec 1;4(S1):P17.

[24] Cheng F, Li W, Zhou Y, Shen J, Wu Z, Liu G, Lee PW, Tang Y. admetSAR: a comprehensive source and free tool for assessment of chemical ADMET properties.

[25] Malik A, Manan A, Mirza MU. Molecular docking and in silico ADMET studies of silibinin and glycyrrhetic acid anti-inflammatory activity. Tropical Journal of Pharmaceutical Research. 2017; 16(1): 67-74.
[26] Strzelecka M, Bzowska M, Koziel J, Szuba B, Dubiel O, Heinrich M, Bereta J. Anti-inflammatory effects of extracts from some traditional Mediterranean diet plants. Journal of Physiology and Pharmacology. Supplement. 2005; 56(1):139-56.

[27] Iwu MW, Duncan AR, Okunji CO. New antimicrobials of plant origin. Perspectives on new crops and new uses. ASHS Press, Alexandria, VA. 1999:457-62.

[28] R Munteanu C, Fernández-Blanco E, A Seoane J, Izquierdo-Novo P, Angel Rodriguez-Fernandez J, Maria Prieto-Gonzalez J, R Rabunal J, Pazos A. Drug discovery and design for complex diseases through QSAR computational methods. Current pharmaceutical design. 2010 Aug 1; 16(24): 2640-55.

[29] Souers AJ, Leverson JD, Boghaert ER, Ackler SL, Catron ND, Chen J, Dayton BD, Ding H, Enschede SH, Fairbrother WJ, Huang DC. ABT199, a potent and selective BCL-2 inhibitor, achieves antitumor activity while sparing platelets. Nature medicine. 2013 Feb; 19(2): 202. 
[30] Sidhu RS, Lee JY, Yuan C, Smith WL. Comparison of cyclooxygenase-1 crystal structures: cross-talk between monomers comprising cyclooxygenase-1 homodimers. Biochemistry. 2010 Jul 29; 49(33): 7069-79.

[31] Orlando BJ, Lucido MJ, Malkowski MG. The structure of ibuprofen bound to cyclooxygenase-2. Journal of structural biology. 2015 Jan 31; 189(1): 62-6.

[32] Silvian LF, Friedman JE, Strauch K, Cachero TG, Day ES, Qian F, Cunningham B, Fung A, Sun L, Su L, Zheng Z. Small molecule inhibition of the TNF family cytokine CD40 ligand through a subunit fracture mechanism. ACS chemical biology. 2011 Apr 20; 6(6): 636-47. 